\title{
Foreign Institutional Ownership and Auditor Choice: Evidence from Worldwide Institutional Ownership
}

\author{
Jeong-Bon Kim \\ University of Waterloo \\ School of Accounting and Finance \\ 200 University Avenue West \\ Waterloo, ON, Canada N2L 3G1 \\ jb6kim@uwaterloo.ca \\ Mikhail Pevzner \\ University of Baltimore \\ Merrick School of Business \\ 1401 North Charles Street, \\ Baltimore, MD 21201, USA \\ mpevzner@ubalt.edu \\ Xiangang Xin* \\ City University of Hong Kong \\ 83 Tat Chee Avenue \\ Kowloon, Hong Kong \\ xiangxin@cityu.edu.hk
}

July 2016

*Corresponding author.

We have received useful comments from Ph.D. seminar/workshop participants from Fudan University, The Open University of Hong Kong, and University of Waterloo. Jeong-Bon Kim and Mikhail Pevzner gratefully acknowledges the assistance received from the Wadsworth Chair at the University of Waterloo's School of Accounting and Finance and the EY Accounting Faculty Chair at the University of Baltimore's Merrick School of Business, respectively. The usual disclaimer applies. 


\title{
Foreign Institutional Ownership and Auditor Choice: Evidence from Worldwide Institutional Ownership
}

\begin{abstract}
We investigate how the demand for higher quality audits outside of the United States is affected by the type of institutional investors, foreign versus domestic. Consistent with the notion that foreign institutional investors (compared to domestic institutional investors) are more informationally disadvantaged, in a large sample of firm-year observations from 41 non-U.S. countries, we find that foreign institutional investors play a more important role in influencing firms' auditor choices. This effect is stronger when the firms they invest in have more severe information asymmetries, either at the country level or at the firm level. We further find that the effect of foreign institutional investors on auditor choice concentrates on institutional investors originating from countries with stronger governance institutions. Overall, our findings suggest that cross-border institutional investment serves as an important channel in influencing firms' auditor choices and improving the information environment of firms around the world.
\end{abstract}

Keywords: Foreign Institutional Investors, Auditor Choice, Information Environment

Data Availability: All data are available from commercial databases identified in the text.

JEL Classification: M40, M41 


\section{Foreign Institutional Ownership and Auditor Choice: Evidence from Worldwide Institutional Ownership}

\section{INTRODUCTION}

Cross-border institutional investment has grown dramatically during the past few decades with the substantial reduction in barriers to international investment. Particularly in the emerging markets, more and more countries seek to boost economic growth by trying to attract investment from foreign institutional investors (FIIs) (Lohade 2016; Cue 2016). On the other hand, FIIs also seek to expand their investment overseas to exploit more profitable investment opportunities which may not be available in the domestic market. However, one essential issue faced by FIIs when they invest overseas is their information disadvantages. Specifically, compared to domestic institutional investors (DIIs), FIIs are often informationally disadvantaged due to geographic distance, unfamiliarity with local industry, economic and regulatory environments, as well as possibly language and cultural barriers (Baik et al. 2013; Kang and Stulz 1997). The information disadvantages of FIIs could further be amplified by informational advantages possessed by DIIs who are likely to have preferential access to firm private information (Choe et al. 2005). It's therefore interesting to explore how FIIs overcome their information disadvantages and influence the information environment of the oversea firms once they have invested in. Specifically, in this study we examine whether the level of foreign institutional ownership (FIO) affects firms' auditor choices in the international setting.

It is well established in the auditing literature that high-quality audits reduce the information asymmetry between firm insiders and outside information users by allowing outsiders to verify the validity of financial statements and the demand for high-quality audits commonly arises as a result of the need for external monitoring (Jensen and Meckling 1976; Watts and Zimmerman 1980; Francis and Wilson 1988). The role of high-quality audits in assuring earnings quality is even more salient in the international setting, given the cross-country variations in disclosure, governance, and investor protection standards (Skinner and Srinivasan 2012; Weber et al. 2008). Therefore, we expect that foreign institutional investors demand 
high-quality audits to reduce the information asymmetry they face and facilitate their monitoring when they invest overseas. Moreover, since prior studies mainly focus on the role of institutional investors in the U.S. firms and there is little evidence on the role of institutional investors outside the U.S., in this study we focus on the impact of the foreign institutional investors (FIIs) on Big 4 auditor choice of non-U.S. firms. ${ }^{1,2}$

Using a sample of 116,516 observations from 41 countries between 2001 and 2011, we find that foreign institutional ownership (FIO) in non-U.S. firms is positively associated with Big 4 auditor choice, suggesting that FIIs demand higher quality audits to reduce the information asymmetry they face when they invest overseas. We also find the positive effect of FIO on auditor choice is stronger than that of domestic institutional ownership (DIO), suggesting that FIIs, compared to DIIs, generally play a more important role in monitoring the firms in which they invest.

We then investigate the cross-sectional variations of the FIO-Big4 auditor choice relation and find that the relation is more pronounced for firms located in countries with more severe information asymmetries, as measured by higher Earning Management index (EM), lower Disclosure Requirement index $(D R)$, or pre-IFRS adoption periods. The FIIs' demand for Big 4 auditors is also stronger among firms with greater ex-ante levels of information asymmetry, as measured by smaller firm size, lower analyst coverage, and higher earnings volatility. These findings suggest that FIIs' demand for high-quality audits increases with the information asymmetry at both country and firm levels.

We further explore the heterogeneity among FIIs and their impact on auditor choice by splitting FIIs in our sample into two groups, 1) institutional investors originating from countries with stronger governance institutions, and 2) institutional investors originating from countries with weaker governance institutions. We expect the institutional investors from countries with stronger governance institutions to have stronger incentives to monitor the firms they invest in because they tend to be more independent and

\footnotetext{
${ }^{1}$ Another reason we exclude U.S. firms from our sample is that U.S. firms are predominantly held by domestic institutional investors (DIIs), while in most countries around the world, the holdings of foreign institutions exceed those of domestic institutions (Aggarwal et al. 2011).

${ }^{2}$ Moreover, U.S. firms are largely audited by Big 4 audit firms. For example, in 2013, Big 4 audit firms audited approximately 93\% of the U.S. Large Accelerated Filers according to Audit Analytics. Therefore, there may be little covariation between institutional ownership and auditor choice in the U.S. firms.
} 
have more expertise to monitor the firms (Aggarwal et al. 2011; Ferraria et al. 2010). Consistent with this conjecture, we find that FIIs from countries with stronger governance institutions, compared to FIIs from countries with weaker governance institutions, are more likely to demand Big 4 auditors. This heterogeneity among FIIs further suggests that FIIs from countries with stronger governance institutions are more likely to play a monitoring role and potentially spread the good governance practices (e.g., high-quality audits) to the countries in which they invest.

A major concern with our empirical findings is the impact of the endogeneity of FIO on the relation between auditor choice and the level of FIO. This is of special concern to us given that prior research finds that institutional investors are more likely to invest in more transparent countries or firms (Bushee and Noe 2000; Chou et al. 2014; Leuz et al. 2010; Yu and Wahid 2014). As a first approach to address this concern, we exploit a quasi-natural experiment setting, namely firms being added to the MSCI All World Index, which is likely exogenous to firms' auditor choice. ${ }^{3}$ Specifically, we conduct a difference-in-differences analysis to examine the effect of index additions on firms' foreign and domestic institutional ownership and auditor choice. We find a significant increase of FIO and Big 4 auditor choice surrounding a firm's addition to MSCI, while there is no significant change in DIO, suggesting that the increase in Big 4 auditor is likely to be triggered by the increase in FIO. We further address the endogeneity concerns by employing twostage least squares (2SLS) regressions in which the FIO level is instrumented by the variable, Proximity, which is measured as the negative value of the weighted average geographical distance between the capital of a firm's home country and the capitals of all the other countries around the world. ${ }^{4}$ We find that the predicted FIO based on this instrumental variable continues to have a positive and significant effect on Big 4 auditor choice. Overall, the results from these two approaches, taken together, suggest that the effect of FIO on auditor choice is unlikely to be driven by endogeneity-based explanations.

\footnotetext{
${ }^{3}$ According to the MSCI's methodology, firms are selected for inclusion based on a number of criteria including floatadjusted market capitalization, trading frequency, trading volume, and percentage of shares open to purchase by foreign investors (MSCI, 2015).

${ }^{4}$ See detailed definition of this variable in section 4.5 .
} 
Lastly, we conduct a variety of additional tests to check the robustness of our findings. First, we try alternative measures of audit quality, including audit fee and auditor industry specialization. Prior studies find a positive association between audit quality and audit fees paid by audit clients (Eshleman and Guo 2014; Lobo and Zhao 2013), and a stream of literature argues that auditor industry specialization is associated with higher quality audits. ${ }^{5}$ We continue to find positive and significant relations between FIO and audit quality using these two alternative measures of audit quality. Moreover, to show that our main findings are not primarily driven by U.S. originating institutional investors, we remove U.S. institutional investors from our calculation of FIO measure, and find that the effect of FIO on Big 4 auditor choice remains significantly positive. Further, since it is harder to define institutions as foreign if the institutions are multinational companies, we remove the top 50 institutions from our sample each year, and recalculate the FIO measure. We continue to find that our main inference on the effect of FIO on Big 4 auditor choice remains unaltered. Lastly, we find that our results are not sensitive to removing several major countries which are over-represented in our sample (i.e., U.K., Canada, and Japan).

Our study contributes to the literature in several ways. First, we investigate the relation between institutional investors and firm auditor choice in an international setting. Prior studies in this area usually focus on a single-country setting such as the U.S. (e.g., Han et al. 2013). We examine the effect of FIIs in an international, multi-country setting, and find that FIIs (compared to DIIs) generally play a more important role in influencing firms' auditor choices. Perhaps more importantly, we find that FIIs from countries with stronger governance institutions are more likely to play a more effective role in influencing firms' auditor choices. Our findings highlight the importance of considering the presence of heterogeneity among foreign institutional investors and show a more complete picture of the impact of institutional investors on firms' auditor choices around the world.

Second, we provide new evidence on the monitoring role of FIIs by showing that FIIs can affect firms' auditor choices. Specifically, prior studies document that international portfolio investment by

\footnotetext{
${ }^{5}$ For example, Carson (2009) finds an audit fee premium for firms with global industry specialization which is consistent with perceived higher audit quality associated with global industry specialists.
} 
institutional investors promotes good corporate governance practices around the world (Aggarwal et al. 2011; Ferreira and Matos 2008; Gillian and Starks 2003). Recent research on corporate governance suggests that effective oversight of firm management by outsiders depends critically on the information available to them (e.g., Bushman and Smith 2001; Bushman and Piotroski, 2006). Our study extends this stand of literature by examining the impact of FIIs on auditor choice, and finds that FIIs can generally improve firms' information environment by demanding firms employing high-quality auditors.

Third, our study provides new insights into the relation between FIIs and corporate transparency around the world. Most prior studies show that investors are generally more likely to invest in firms or countries with better disclosure practices or a higher level of corporate transparency (Chou et al. 2014; DeFond et al. 2011; Leuz et al. 2010). Our study, on the other hand, highlights the monitoring role of FIIs relative to DIIs and investigates whether FIIs can increase the transparency of local firms once they have invested in. The findings from our study can therefore create a deeper understanding of the interactions between FIIs and corporate transparency.

The remainder of the paper is structured as follows. In Section 2 we review the related literature and develop our hypotheses. Section 3 describes the data, key variables, and research design. Section 4 presents the empirical analysis. We conclude in Section 5.

\section{LITERATURE REVIEW AND HYPOTHESIS DEVELOPMENT}

\section{Prior Research on Auditor Choice}

High-quality audits reduce the information asymmetry between firm insiders and outside information users by allowing outsiders to verify the validity of financial statements (Jensen and Meckling 1976; Watts and Zimmerman 1980). Consistent with the auditors' information verification role, prior research shows that higher quality auditors are associated with higher earnings quality (Becker et al. 1998), greater credibility of earnings news (Teoh and Wong 1993), higher audit fees (Choi et al. 2008), more informative voluntary disclosure policies (Ball et al. 2012; DeFond and Zhang 2014), and lower cost of 
debt and equity capital (Chang et al. 2009; El Ghoul et al. 2015; Gul et al. 2013; Mansi et al. 2004; Pittman and Fortin 2004).

Consistent with the role of high-quality audits in reducing the information asymmetry, the demand for such audits commonly arises as a result of the need for external monitoring on behalf of external shareholders and debtholders (Francis and Wilson 1988). For example, prior studies show that high-quality auditors are demanded by East Asian firms with high agency conflicts between controlling shareholders and minority shareholders (Fan and Wong 2005), by French companies with less family control and more diversified ownership (Francis et al. 2009), by Canadian companies with large differences between cash flow rights and control rights (Khalil et al. 2008), and by U.K. unlisted firms with either low or high managerial ownership (Lennox 2005). Consistent with these findings, in a cross-country study, Choi and Wong (2007) further find that auditors serve a more significant governance function in countries with weaker legal systems.

\section{Prior Research on Foreign Institutional Investors}

From the standpoint of institutional investors, the ex-ante level of information asymmetry is lower for domestic firms in the domestic market than for overseas firms in the foreign market because they are more familiar with legal, cultural, and disclosure aspects of the domestic market. Foreign institutional investors (FIIs) thus face a conundrum: On one hand, they want to seek out more profitable investment opportunities abroad which may not be available in the domestic market, thus requiring greater risk taking; on the other hand, they could be concerned with losing their investment in the foreign market in which they are informationally disadvantaged.

Consistent with the latter notion, prior research on foreign institutional ownership suggests that foreign institutions prefer to invest in larger, more well-recognized firms which are also cross-listed in the U.S. (Ferreira and Matos, 2008); U.S. mutual funds prefer to invest in "emerging markets with stronger

accounting standards, shareholder rights and legal standards" (Aggarwal et al. 2005). Dahlquist and Robertsson (2001) show that foreign investors prefer to invest in larger, more cash-rich Swedish firms 
which are not dominated by a single individual; the results are even more pronounced among U.S. institutions. Leuz et al. (2010) show that foreign investors are less likely to invest in firms which have more concentrated ownership structures, thus making minority shareholders more vulnerable, and also in firms located in countries with poorer shareholder protections and disclosure requirements. DeFond et al. (2011) show that greater comparability of accounting standards caused by the adoption of IFRS is associated with increases in foreign mutual fund ownership. Similarly, Covrig et al. (2007) find that foreign mutual fund holdings are higher in countries that followed IAS, especially among firms in poorer information environments and with lower visibility. Thus, overall evidence seems to suggest that foreign institutions prefer to invest in lower risk, better governed foreign markets, characterized by more informative disclosure and more transparent accounting.

However, some evidence exists that foreign institutional investors do not completely shy away from investing in countries with weaker governance regimes. On the contrary, once invested in foreign firms, institutional investors have strong incentives to monitor the firms in order to maximize the value of their investment. For example, Ferreira et al. (2010) show that firms with higher foreign institutional ownership experience more positive target or acquirer announcement returns, since foreign institutions act as "bridge-builders" between domestic and foreign markets by facilitating cross-border mergers. Aggarwal et al. (2011) further provide evidence that changes in foreign institutional ownership positively affect subsequent changes in firm-level governance. More specifically, they find firms with higher institutional ownership are more likely to terminate poorly performing CEOs. Fang et al. (2015) show that U.S.-based foreign institutional investors drive firms to adopt accounting practices more comparable to those of U.S. firms. Tsang et al. (2015) show that foreign institutional investors are associated with stronger demand for more frequent, more specific, disaggregated, and more informative management forecasts. Taken together, prior studies on foreign institutional investors (FIIs) suggest that while FIIs prefer lower levels of information risk, they are also willing to help improve governance and in the process improve shareholder value once they have invested in foreign firms. 


\section{Testable Hypotheses}

Collectively, prior studies suggest that on the one hand, high-quality audits reduce the information asymmetry between firm insiders and outside information users by increasing credibility of earnings information, and the demand for high-quality audits arises as a result of the need for external monitoring. On the other hand, FIIs may face severe information asymmetry when they invest overseas since it is difficult or costly for them to understand and interpret accounting information of the oversea firms. Specifically, compared to domestic institutional investors (DIIs), FIIs are often informationally disadvantaged due to geographic distance, unfamiliarity with local industry, economic and regulatory environments, as well as possibly language and cultural barriers (Baik et al. 2013; Kang and Stulz 1997). Moreover, such informational friction is potentially amplified by informational advantages possessed by DIIs who could have preferential access to information and additional economic protections from the local governments (Choe et al. 2005). Thus, we posit that FIIs have stronger incentives to demand high-quality audits to facilitate their monitoring once they have invested in the overseas firms.

However, it is also possible that FIIs may play a less influential role than DIIs in monitoring. Prior research shows that institutional investors located closer to firms are more effective monitors due to their better access to firm private information and lower costs of monitoring (Ayers et al. 2011). In contrast, FIIs face higher costs and more difficulty in monitoring firm managers abroad because of their geographic and cultural distances and information disadvantages (Leuz et al. 2010). Therefore, it is also conceivable that FIIs have a weakened ability to influence firms' auditor choices. Combining the above two competing arguments, our first hypothesis is non-directional.

H1: Foreign institutional ownership is associated with the probability of appointing a Big 4 auditor.

The monitoring role of FIIs is expected to be stronger when ex-ante information asymmetry is higher (Ferreira et al. 2010; Guedhami et al. 2009). In the cross-country setting, the information asymmetry faced by foreign institutional investors can be driven either by country- or firm-level characteristics. The 
country-level information asymmetry could be caused by the lack of investor protection, disclosure, and enforcement mechanisms, which may lead to lower earnings quality (Leuz et al. 2003), less transparent disclosure, and so on. The firm-level information asymmetry could be driven by firm-specific factors, such as less firm-level disclosure, less analyst following, or higher earnings volatility. Our basic conjecture is that foreign institutions exhibit greater demand for higher quality audits, especially when the firms they invest in have higher country- or firm-level information asymmetry. This leads us to the following prediction:

H2: The association between FIO and the probability of firms appointing a Big 4 auditor is stronger for firms with higher information asymmetry.

\section{SAMPLE SELECTION AND RESEARCH DESIGN}

\section{Sample Selection}

To construct our sample, we begin with 409,919 firm-year observations from non-U.S. countries in the Worldscope database for the period of 2001-2011. Our sample period starts in 2001 because institutional ownership in FactSet/LionShares (discussed below) starts from 1999 but the coverage is very limited in the first two years. We then extract auditor choice data from Worldscope and end up with 356,897 observations. Out of these observations, we further drop observations with missing values for the necessary control variables (e.g., firm size, leverage, industry information) and obtain a sample of 226,593 observations.

We then merge Worldscope data with the FactSet institutional ownership data. FactSet covers a comprehensive sample of international firms and provides detailed information on the ownership of each firm by funds or institutions by compiling institutional ownership data from public filings by investors (e.g., 13-F filings in the U.S.), company annual reports, stock exchanges, and regulatory agencies around the world. There are two main databases in FactSet: the aggregate institutional filings and the mutual fund database. The institutional database will be used as the primary database, while the ownership information from the mutual fund database will be added if the parent institution's holdings are not in the institutional 
ownership database. As institutions from different countries have different reporting frequencies, we follow prior studies (e.g., Ferreira and Matos, 2008) and use the latest holding update at each year-end. We also obtain information on the type (e.g., mutual fund managers, investment advisers, bank trusts, pension funds, insurance companies) and country origin of each institutional investor from FactSet.

After we merge institutional ownership data to our sample, we get 121,528 observations. Lastly, we drop observations without necessary country-level variables, such as earnings management and opacity scores based on Leuz et al. (2003), the disclosure requirement index (La Porta et al. 2006), the anti-director index (Djankov et al. 2008), the law origin data (La Porta et al. 1999), and the security regulation index (La Porta et al. 2006). Our final sample consists of 116,516 observations in 41 countries for the period of 2001-2011.

\section{Main Variables}

\section{Auditor Choice}

Following prior literature, Big4 is defined as an indicator variable which equals one if a firm employs a Big 4 auditor as identified by Thomson Worldscope “Translation Taxonomy” of Big 4 or Big 5 auditor names, and zero otherwise. ${ }^{6}$ Because Big 4 auditor names vary widely around the world, Worldscope Auditor Taxonomy identifies which audit firms are associated with Big 4 audit names (or with Big 5 auditor names prior to dissolution of Arthur Andersen in 2002). The large majority of auditor names in the Taxonomy partially contain traditional Big 4 (Deloitte, EY, KPMG, or PwC) or Big 5 (adding Arthur Anderson to the preceding list) auditor names; however, in some cases, the auditor type is not obvious from reading the auditor name (for example, Kesselman and Kesselman is a PwC-affiliated firm in Israel).

\section{Foreign Institutional Ownership}

A firm's total institutional ownership $(T I O)$ is measured as the percentage of shares (end-of-year) held by all types of institutional investors. $T I O$ is further decomposed into foreign and domestic institutional

\footnotetext{
${ }^{6}$ We obtain the time series auditor information from Excel Addin of Thomson Worldscope.
} 
ownership according to the country origin of each institutional investor. Foreign institutional ownership (FIO) is the percentage of a firm's shares held by all institutions domiciled in a country that is different from the country in which the firm is located. Domestic institutional ownership $(D I O)$ is the percentage of a firm's shares held by all institutions domiciled in the same country where the firm is located.

We also consider the heterogeneity of FIIs and decompose foreign institutional ownership into two subgroups based on the median of country-level governance institutions in our sample: (i) FIO from countries with stronger governance institutions (FIO_HighGov), and (ii) FIO from countries with weaker governance institutions (FIO_LowGov). FIO_HighGov (FIO_LowGov) is the percentage of shares (end-ofyear) held by foreign institutional investors from countries with higher (lower) quality corporate governance provisions. The corporate governance institutions are measured by one of the following three indices: (i) the investor protection index (IP), or anti-director rights index from Djankov et al. (2008); (ii) the law origin $(L W)$, common law or code law; and (iii) the securities regulation $(S R)$ index as defined by Hail and Leuz (2006). The $S R$ index is measured as the average of the disclosure requirement index, the liability standard index, and the public enforcement index from La Porta et al. (2006).

\section{Control Variables}

We draw on the extant literature to identify and control for a wide range of firm and industry characteristics that may influence firms' auditor choices (Choi and Wong 2007; Francis et al. 1999; Guedhami et al. 2014). Detailed definitions of all variables are provided in the Appendix. Specifically, we control for firm size (Size), capital intensity (Capex), inventory and receivables (InvRec), and segments (Segs). These four variables are used in prior studies to measure the scale and complexity of a firm, which affects the level of efforts that an auditor expends to produce a desired level of audit quality. More specifically, firm size (Size) is defined as the log of year-end total assets in thousands of U.S. dollars; Capital intensity (Capex) is defined as the long-term assets scaled by total assets; Inventory and receivables $($ InvRec) is defined as year-end inventory and accounts receivable scaled total assets; and the variable 
capturing the number of segments (Segs) is measured by the log of 1 plus the number of business segments of the firm.

We also control for leverage (Leverage) and profitability (ROA). These two variables are associated with the probability of a client's financial distress, which is related to the auditor's litigation risk. More specifically, leverage (Leverage) is measured as year-end total liabilities over total assets; profitability $(R O A)$ is measured as net income divided by total assets by the end of the year.

Finally, we also control for several other variables that are deemed to influence a firm's auditor choice. We control for foreign sales (Fsale), which is measured as a ratio of foreign sales to total sales; assets growth (Growth), which is measured as the percentage change in assets as compared to the prior year; and financing activity (Finance), which is measured an indicator variable equal to one if long-term debt increased by 20 percent or more or the number of shares outstanding increased by 10 percent or more, and zero otherwise. Prior studies suggest firms with more foreign sales, higher growth, and firms with debt or equity issuance are more likely to hire Big 4 auditors (e.g., Choi and Wong 2005; Guedhami et al. 2014).

\section{Research Design}

To test hypothesis $\mathrm{H} 1$ regarding the effect of foreign institutional ownership (FIO) on firms' auditor choices, we estimate the following logit regression model (firm subscripts are omitted for parsimony).

$$
\begin{aligned}
\text { Big }_{t}=\alpha_{0} & +\alpha_{1} \text { FIO }_{t-1}+\alpha_{2} \text { DIO }_{t-1}+\alpha_{3} \text { Size }_{t}+\alpha_{4} \text { InvRec }_{t}+\alpha_{5} \text { Capex }_{t}+\alpha_{6} \text { Seg }_{t}+\alpha_{7} \text { ROA }_{t} \\
& +\alpha_{8} \text { Leverage }_{t}+\alpha_{9} \text { Fsale }_{t}+\alpha_{10} \text { Growt }_{t}+\alpha_{11} \text { Finance }_{t}+\text { fixed effects }+\varepsilon
\end{aligned}
$$

If foreign institutional investors (FIIs) demand high-quality audits, we expect to find that $\alpha_{1}$ is positive and significant. Moreover, if $F I O$ can play a more important role than $D I O$ in external monitoring by demanding firms to appoint high-quality auditors like the Big 4, we expect to observe that $\alpha_{1}>\alpha_{2}>0$.

To test our hypothesis $\mathrm{H} 2$, which predicts that coefficient $\alpha_{1}$ will be higher and more positive in firms with higher country-level or firm-level information asymmetry, we partition our sample into subsamples based on country-level information environment variables, including the Earnings Management index $(E M)$, the Disclosure Requirement index $(D R)$, and the IFRS adoption indicator $(I F R S)$, as well as on 
firm-level information asymmetry proxied by firm size, analyst coverage, and earnings volatility. The variables Earnings Management index $(E M)$, Disclosure Requirement index $(D R)$, and firm size are as defined earlier. Analyst coverage is measured as the number of analysts following a firm, and earnings volatility is measured as the standard deviation of earnings in the previous five years. We then partition the total sample into two subsamples based on the median value of each partition variable and then estimate regression model (1) for each partitioned subsample. Finally we perform a Chi-square test to formally compare differences in the coefficient $\alpha_{1}$ between the two partitioned subsamples.

In further analyses, we examine whether the impact of foreign institutional investors (FIIs) on firms' auditor choices varies with FIIs' home country governance institutions. To this end, we further decompose FIO into FIO from countries with strong governance institutions (FIO_HighGov) and FIO from counties with weak governance institutions (FIO_LowGov), and then estimate the following regression model. We expect to find that the monitoring role of FIIs concentrates on FIIs from countries with strong governance institutions (FIO_HighGov), that is, $\alpha_{1}$ is positive and significant in the following regression model, while $\alpha_{2}$ is insignificant.

$$
\begin{aligned}
\text { Big }_{t}= & \alpha_{0} \\
+ & \alpha_{1} \text { FIO }_{\text {HighGov }, t-1}+\alpha_{2} \text { FIO }_{\text {LowGov }, t-1}+\alpha_{3} \text { DIO }_{t}+\alpha_{4} \text { Size }_{t}+\alpha_{5} \text { InvRec }_{t}+\alpha_{6} \text { Capex }_{t}+\alpha_{7} \text { Segs }_{t} \\
& +\alpha_{8} \text { ROA }_{t}+\alpha_{9} \text { Leverage }_{t}+\alpha_{10} \text { Fsale }_{t}+\alpha_{11} \text { Growt }_{t}+\alpha_{12} \text { Finance }_{t}+\text { fixed effects }+\varepsilon
\end{aligned}
$$

We estimate all regressions while controlling for year and industry fixed effects. To reduce the influence of outliers, all continuous variables are winsorized at their 1 st and 99 th percentiles. The standard errors are adjusted for heteroskedasticity and firm-level clustering (Petersen, 2009).

\section{EMPIRICAL RESULTS}

\section{Summary Statistics}

Table 1 reports the country distribution of observations and country means of foreign and domestic ownership and Big 4 concentration for each of 41 non-U.S. countries in our worldwide sample. The total number of observations in a given country ranges from 63 for Jordan to 24,586 for Japan. The percentage of firms hiring a Big 4 auditor ranges from $19 \%$ in India to $98 \%$ in Chile. The country mean of FIO also 
exhibits significant variation among our sample countries: Jordan has the lowest FIO $(0.5 \%)$ while the Netherlands has the highest FIO (14.1\%). The country mean of FIO is higher than that of DIO in most countries in our sample, suggesting that FIO may generally have comparable or even stronger influence over firms' financial reporting decisions and auditor choices in our worldwide sample. In the last two columns, we further calculate the value weighted average of FIO and DIO in each country, that is, the value of shareholdings by FIIs in a country divided by stock market value in the same country. We again find that FIO is generally higher than DIO in most countries. Moreover, we find greater value of FIO in the value weighted form, reflecting the fact that FIIs tend to invest more in larger firms or firms with larger market capitalization (Dahlquist and Robertsson 2001; Kang and Stulz 1997). We note that the descriptive statistics of FIO and DIO in our paper are in line with those reported in prior studies using FactSet/LionShares institutional ownership data (e.g., Aggarwal et al. 2011).

\section{[Insert Table 1 about Here]}

Table 2 provides overall summary statistics for firm-year observations in our sample. The mean of Big4 is $67.4 \%$, which is largely consistent with prior work (e.g., Kim et al., 2012). The average total institutional ownership is $9.9 \%$, while the mean FIO $(D I O)$ is $4.8 \%(5.1 \%)$, which further underscores the importance of FIO, which is comparable to DIO in the non-U.S. countries. With respect to firm-level controls, the average (median) firm in our sample has a logarithm of total assets (Size) of 19.410 (19.336), an inventory and receivables ratio (InvRec) of 0.302 (0.290), a capital intensity ratio (Capex) of 0.323 (0.284), a return on assets $(R O A)$ of $0.000(0.031)$, a leverage ratio (Leverage) of 0.124 (0.073), an annual assets growth rate (Growth) of 0.226 (0.089), and a foreign sale ratio (Fsale) of 0.193 (0.000). Moreover, an average firm has 1.294 segments (Segs) and 38.2\% of the observations in our sample have significant financing activities (Finance). These summary statistics are largely consistent with prior studies in the literature.

[Insert Table 2 about Here] 


\section{Baseline Regression}

Table 3 provides the results of the estimation of our baseline logit regression in model (1) on the effect of foreign institutional ownership (FIO) on Big 4 auditor choice. In column 1, we first estimate an association between total institutional ownership (TIO) and auditor choice without including the control variables. We find a positive association between the two, suggesting institutional investors generally demand that firms hire high-quality auditors. In columns 2 and 3, we decompose TIO into FIO and DIO. As shown in column 2, we find that the coefficient on $F I O$ is positive and significant $(4.570$ with $t$-value $=$ 22.74). The finding is consistent with H1, suggesting that foreign institutional investors (FIIs) demand highquality audits to facilitate their monitoring once they have invested in the overseas firms. Moreover, we continue to find a positive and significant effect of $F I O$ on auditor choice in column 3 when we include a range of control variables in the regression.

Further, we compare the effect of $F I O$ with that of $D I O$ on auditor choice. We first find that $D I O$ is also positively associated with Big 4 auditor choice, suggesting DIIs can on average play a role of external monitoring by demanding that firms appoint high-quality auditors like the Big 4 . However, we find that the coefficient on $F I O$ is more than three times greater in magnitude than that on $D I O$ in column 2 (4.570 versus 1.513), and about twice greater than that on DIO in column 3 (1.278 versus 0.670$)$, suggesting that the effect of $F I O$ on Big 4 auditor choice is much stronger than that of DIO. We further estimate the Chi-square statistic for testing the difference between the $F I O$ and $D I O$ coefficients and find that the difference is significant (3.71 in column 3, significant at the 5\% level). These results are consistent with our expectation that FIIs play a more important role than DIIs in monitoring firms in the non-U.S. international setting.

\section{[Insert Table 3 about Here]}

With respect to the control variables, we find that large firms and firms with complex transactions tend to hire Big 4 auditors. Specifically, we find that the coefficients on firm size (Size), inventory and receivables ratio (InvRec), capital investment intensity (Capex), number of segments (Segs), and foreign sales (Fsale) are all positive and significant. We also find that more profitable firms $(R O A)$ are more likely 
to hire Big 4 auditors. Furthermore, consistent with Guedhami et al. (2014), high growth firms (Growth) are less likely to hire Big 4 auditors and the relation between financing activities (Finance) and auditor choice is not significant in our sample.

\section{Cross-sectional Variations in the FIO-Big 4 Relation}

\section{Country-level Information Asymmetry}

To test our hypothesis $\mathrm{H} 2$, we now examine whether the positive relation between $F I O$ and $\mathrm{Big} 4$ auditor choice varies systematically with country-level or firm-level information asymmetry measures. In Table 4, we explore how the relation between FIO and Big 4 auditor choice is impacted by country-level information asymmetry measures. Specifically, in Panel A, we partition our sample into two subsamples based on the median of the country-level information environment variables, the Earning Management index (EM) developed by Leuz et al. (2003), and then estimate our model (1), separately, for two subsamples. ${ }^{7}$ We find that $F I O$ exhibits much stronger association with Big 4 auditor choice in the higher $E M$ (or lower earnings quality) subsample, while in the lower $E M$ (or higher earnings quality) subsample, the relation between $F I O$ and Big 4 auditor choice is insignificant. We then use a Chi-square test to formally test the difference in the coefficient magnitude between the two subsamples, and find the difference is significant at the $5 \%$ level $(\mathrm{Chi} 2(1)=4.61)$. These findings support our hypothesis $\mathrm{H} 2$ that the demand for a Big 4 auditor is much stronger when foreign investors face higher information asymmetry in the countries they invest.

We then compare the difference between DIO in these two subsamples, and find that DIIs demand high-quality audits in countries with lower $E M$ (or higher earnings quality). In countries with higher $E M$ (or lower earnings quality), the effect of DIO on Big 4 auditor choice is negative although insignificant, which is consistent with the findings of Maffett (2012) that institutional investors in countries with high information asymmetry are likely to be informed traders who can benefit from an opaque information

\footnotetext{
${ }^{7}$ We lose 5,722 observations due to the missing value of the Earning Management index.
} 
environment. Perhaps more importantly, to the extent that private information acquisition by DIIs increases the information asymmetry faced by FIIs, this further explains why FIIs strongly demand high-quality audits in countries with higher $E M$.

We then compare the difference between the FIO and DIO coefficients within these two subsamples, respectively. We find that FIIs demand high-quality audits in countries with higher $E M$, compared to DIIs, while in countries with lower $E M$, the difference between the coefficients on $F I O$ and $D I O$ is insignificant. This finding suggests that the stronger effect of FIO (compared to DIO) on highquality auditor choice is concentrated more in countries with higher information asymmetries proxied by higher $E M$.

We observe very similar results when we partition our sample based on the strength of Disclosure Requirement $(D R)$ in Panel B of Table 4. The coefficient on FIO in column 1 (lower DR subsample) is significantly larger than the coefficient in column 2 (higher $D R$ subsample), therefore, the association between $F I O$ and Big 4 auditor choice is more pronounced in countries with lower $D R$ regimes or higher information asymmetry. Similarly, we find that DIIs demand high-quality audits in countries with high $D R$, while in countries with low $D R$, DIIs are less likely to demand Big 4 auditors.

Prior work shows that IFRS adoption results in greater information transparency and comparability among firms (e.g. Byard et al. 2011; Horton et al. 2013; Kim et al. 2012), and thus provides us with a unique setting to test the effect of information asymmetry on the demand of FIIs for high-quality audits. Because IFRS adoption represents an exogenous shock to a firm's information environment, we can better identify a causal reference on the effect of $F I O$ on Big 4 auditor choice. ${ }^{8}$ We first create an indicator variable which equals one if a country-year is for a country which has adopted IFRS and a year which is during the postadoption period $(I F R S=1)$, and zero otherwise. We then partition our sample into two subsamples based on this indicator variable, and estimate our baseline regression model (1), separately, for these two subsamples. The regression results are reported in Panel $\mathrm{C}$ of Table 4. We find that the positive relation between FIO

\footnotetext{
${ }^{8}$ This is similar, for example, to the approach employed in Aier et al. (2014), Armstrong et al. (2012), and Kim et al. (2012).
} 
investment and Big 4 auditors is significant in both subsamples but the coefficient on FIO is significantly larger in the pre-IFRS adoption subsample. This is consistent with our expectation that the demand for Big 4 auditors by FIIs is higher when information uncertainty is stronger. In contrast, we find the effect of DIO on auditor choice is significant in both subsamples and does not differ significantly between these two subsamples.

\section{[Insert Table 4 about Here]}

Collectively, we find significant and robust results that the Big 4 auditors are in greater demand by FIIs in countries with higher levels of information asymmetry, as evidenced by all three country-level information asymmetry measures. These results provide strong support to our hypothesis H2 that FIIs' demand for Big 4 auditors is stronger when the information asymmetry faced by them is more severe at the country level.

\section{Firm-level Information Asymmetry}

To further test $\mathrm{H} 2$, we now partition our sample into two subsamples using the median cuts, based on firm-level information asymmetry proxies, including firm size, analyst coverage, and earnings volatility. It is well documented in previous literature that large firms, firms with higher analyst coverage, and firms with less-volatile earnings have lower information asymmetry. Specifically, we partition our sample into two subsamples in each country-year based on the median of these three variables, respectively. We then estimate our logit regression model in regression model (1), separately, for these two subsamples.

We report the regression results in Table 5. We find that the positive association between FIO and Big 4 auditor choice is concentrated significantly on small firms (Panel A), firms with low analyst coverage (Panel B), and more pronounced among firms with higher stock return volatility (Panel C). The difference in the FIO coefficient between the two subsamples is significant in all three panels, as suggested by the Chi-square test in the last column. We further compare the coefficients on DIO in high versus low firmlevel information asymmetry subsamples, and find that the difference is insignificant across all three panels, suggesting DIIs' demand for high-quality audits is insensitive to the information asymmetry. Overall, these 
findings suggest FIIs (compared to DIIs) strongly demand high-quality audits to facilitate their monitoring when information asymmetry is more severe. These results thus lend further support to our hypothesis $\mathrm{H} 2$ that FIIs' demand for high-quality audits increases with firm-level information asymmetry.

\section{[Insert Table 5 about Here]}

\section{The Heterogeneity among FIIs and FIO-Big 4 Relation}

So far, we find a positive effect of $F I O$ on Big 4 auditor choice, and this effect is stronger when firms are located in countries with higher information asymmetry, or when firms have higher firm-level information asymmetry. We then further explore the heterogeneity among FIIs; specifically, we examine whether the institutional investors' originating country matters for their demand for high-quality audits. Prior studies suggest that institutional investors originating from countries with stronger governance institutions, compared to institutional investors originating from countries with weaker governance institutions, have stronger incentives and the ability to monitor the firms in which they invest, since they are more independent and have more expertise to monitor the firms (Aggarwal et al. 2011; Ferraria et al. 2010). We therefore expect that FIIs from countries with stronger governance institutions are more likely to demand for Big 4 auditors.

To test this conjecture, we decompose FIO into two components: (i) FIO from countries with stronger governance institutions (FIO_HighGov), and (ii) FIO from countries with weaker governance institutions (FIO_LowGov), where country-level governance is measured by Investor Protection (IP), Law Origin $(L W)$, and Security Regulations $(S R)$, respectively. We then estimate our logit model in regression model (2) and report the estimation results in Table 6. We find that FIO from countries with higher governance institutions (FIO_HighGov) is more likely to demand Big 4 auditors, while the effect of FIO from lower governance countries (FIO_LowGov) is insignificant or significantly negative in all the three columns. These results suggest that FIIs originating from countries with stronger governance institutions are more likely to play a governance role and therefore influence the firms' auditor choices. The results also suggest that the effect of FIIs on auditor choice mainly concentrates on FIIs from countries with 
stronger governance institutions. The implication of these findings is that FIIs from countries with stronger governance institutions can potentially spread the good governance practices (e.g., high-quality audits) to the countries they invest in through their cross-border investment.

\section{[Insert Table 6 about Here]}

\section{Mitigating Endogeneity Concerns}

A major concern with our empirical investigation is the endogeneity of foreign institutional ownership (FIO). More specifically, FIO is not distributed randomly across countries and across firms. Prior literature suggests institutional investors are more likely to invest in more transparent countries or firms (Bushee and Noe 2000; Chou et al. 2014; Leuz et al. 2010; Yu and Wahid 2014). Failure to adequately control for these factors would introduce the omitted variable bias into our analysis, making it difficult to draw reliable inferences regarding the relation between $F I O$ and auditor choice. In this section we conduct several tests to address the identification challenge and bolster our confidence in a causal interpretation that foreign institutional ownership leads to high-quality auditor choice.

\section{Quasi-natural Experiment Based on MSCI Index additions}

Our first identification strategy is to exploit a quasi-natural experiment ${ }^{9}$ created by firms being added to the MSCI All World (MSCI) Index. ${ }^{10}$ According to the MSCI's methodology, firms are selected for inclusion based on a number of criteria including float-adjusted market capitalization, trading frequency, trading volume, and the percentage of shares open to purchase by foreign investors (MSCI 2015). ${ }^{11}$ Therefore, a firm's addition to the MSCI Index is largely exogenous to its auditor choice. However, addition to the MSCI index is generally followed by large increases in FIO, either because of index constituent firms' greater visibility to foreign investors or because of many international portfolio managers' need or tendency to closely track the MSCI Index. Taking advantage of these attractive features, we now perform

\footnotetext{
${ }^{9}$ Many prior studies use exogenous legal or transparency shocks to control for endogeneity and establish causal inference (e.g., Aier et al. 2014; Armstrong et al. 2012).

${ }^{10}$ A similar approach is employed in Bena et al. (2015) and Boone and White (2014).

${ }^{11}$ Available at https://www.msci.com/eqb/methodology/meth docs/MSCI_Nov2015 GIMIMethodology.pdf.
} 
a difference-in-differences analysis to examine the effect of index additions on firms' foreign and domestic institutional ownership and auditor choice, respectively.

Specifically, we employ a five-year window around MSCI index additions with index additions occurring between year -1 and year 0. We obtain a sample of index additions in the 2002-2009 period, when there are 399 additions to the MSCI for which we have complete institutional ownership (both FIO and $D I O)$ data and Big 4 auditor choice data in the two-year period before and after the event. We then formally estimate the difference-in-differences regressions in an effort to examine the effect of MSCI index addition on FIO, DIO and Big 4 auditor choice (Big4). These 399 index additions are our treated firms. Post is coded as 1 for years after the addition event and zero otherwise. Control firms are the neighbor firms that are from the same country and year but not added to MSCI index, have the same auditor choice (Big4) in year -1, and have the closest foreign institutional ownership (FIO) in year -1. In an additional test, we find that FIO is not significantly different between treatment and control groups in year -1 .

The estimation results are presented in Table 7. As shown in column 1 of the table, we find that compared to the control group, foreign institutional ownership $(F I O)$ in firms of the treated group increases significantly, on average, by $3.4 \%$ around the time a firm is added to the MSCI. In sharp contrast, we find that the coefficient on Treated $\times$ Post in column 2 is insignificant, suggesting that there is no corresponding change in DIO. Therefore, a firm's addition to the MSCI is indeed an exogenous shock for foreign (but not domestic) institutional ownership. More importantly, in column 3, we find a significant increase in Big 4 auditor choice (Big4) around the time a firm is added to the MSCI index. Since MSCI index addition is exogenous to a firm's auditor choice, the increase in Big 4 auditor choice (Big4) around MSCI index addition event can be mainly triggered by the increase in FIO. Moreover, it's also less likely that the increases in both $\mathrm{FIO}$ and Big4 are driven by some omitted variables related to MSCI index additions (e.g., market capitalization, profitability), since such variables would drive all institutional investors (foreign and domestic) to increase their stock holdings. Overall, the results from MSCI index additions suggest that the positive relation between $F I O$ and Big 4 auditor choice (Big4) cannot be easily explained by reverse causality or some omitted variables. 
[Insert Table 7 about Here]

\section{Instrumental Variable Approach}

We further address the endogeneity concern by employing two-stage least squares (2SLS) regressions in which we introduce one instrument variable for a firm's foreign institutional ownership. The instrument, Proximity, is a geographic proximity measure based on the intuition that institutional investors prefer to invest in firms located in geographically proximate countries when they invest abroad. Prior studies show institutional investors prefer to invest in near firms within a country (e.g., Ayers et al. 2011). The variable is measured as the negative value of the weighted average geographical distance between the capital of a firm's home country and the capitals of all the other countries around the world. The weight for each of the other countries is the institutional investment outflow from that country in a given year divided by the aggregate institutional investment outflows from all countries in the same year. ${ }^{12}$ As the weights vary from year to year, so does the instrument. Our instrument appears to satisfy the exclusion restriction as the geographic distance does not present any direct, economic link to firms' reporting and auditing practices.

We report the 2SLS regression results in Table 8. Column 1 shows the first-stage results. We find that our instrument variable has a positive and significant coefficient as shown in column 1, consistent with our expectation that $F I O$ is higher for firms located in countries with a shorter weighted average distance from the other countries. Column 2 reports the second-stage regression results where the dependent variable

\footnotetext{
${ }^{12}$ Consider four countries in the world, A, B, C, and D. Suppose we have a firm in country A that is the potential recipient of cross-border investment by institutional investors from country B, C, and D. Further suppose that in a particular year, the total institutional investment outflows from country B, C, and D to the rest of the world are $\$ 200$, $\$ 300$, and $\$ 400$, respectively. The weighted average distance between our firm's home country A and the other three countries is computed as [distance $(\mathrm{A}, \mathrm{B}) \times 200 /(200+300+400)+$ distance $(\mathrm{A}, \mathrm{C}) \times 300 /(200+300+400)+$ distance $(\mathrm{A}, \mathrm{D}) \times 400 /(200+300+400)]$. The reason we give the distance between $\mathrm{A}$ and $\mathrm{D}$ the largest weight is that $\mathrm{D}$ represents the largest source of cross-border institutional investment in the world (such as the U.S.). Therefore, the distance between $\mathrm{A}$ and $\mathrm{D}$ should have the largest impact on how much total foreign institutional investment our firm in country A will receive. We do not believe this weighting scheme affects the exogeneity of the proximity instrument, because the total institutional investment outflow from countries B, C, and D to all other countries in the world is unlikely to be driven by the disclosure practice of any single country such as A. Nevertheless, we also construct proximity based on the unweighted, simple average of the geographic distance between countries and continue to find robust results.
} 
is auditor choice (Big4). We find that the instrumented version of FIO (FIO_Predicted) still has a significantly positive coefficient, suggesting that our earlier findings still hold after we correct potential endogeneity with respect to $F I O$. The results from 2 SLS further suggest that the observed effect of $F I O$ on auditor choice is unlikely driven by potential endogeneity-based explanations.

\section{[Insert Table 8 about Here]}

\section{Robustness Tests}

In Table 9, we summarize a variety of robustness tests we perform. First, we use audit fee to measure audit quality since prior studies suggest audit quality is positively related with audit fee (Eshleman and Guo, 2014). We use the log form of audit fee as the dependent variable in lieu of Big4 in regression model (1), and then estimate it using the OLS procedure. As shown in column 1, the result of the OLS regression shows that the coefficient on FIO is significantly positive. Second, we use auditor industry specialization to measure audit quality following Carson (2009). As shown in column 2, we continue to find that the positive effect of $F I O$ on auditor quality still holds.

Third, to show that our main findings are not driven by U.S. institutional investors, we remove U.S. institutional investors from the institutional investor sample and recalculate the $F I O$ measure. As shown in column 3, we still find a positive effect of FIO on Big4 using this new measure of FIO. Fourth, another potential problem to our FIO measure is that some institutions, especially very large institutions, are multinational companies, which makes it difficult to identify their country origins and define whether they are foreign institutional investors. To mitigate this problem, we remove the top 50 institutions each year from our sample, and recalculate the $F I O$ measure. As reported in column 4, the results using this measure of $F I O$ suggest that the main reference on the effect of FIO on Big4 does not change. Lastly, as presented in

column 5, we find our results are not sensitive to removing major countries which are over-represented in our sample, i.e., the United Kingdom, Canada, and Japan, suggesting our findings are not driven by one or several specific countries in our sample.

[Insert Table 9 about Here] 


\section{CONCLUSION}

Our paper investigates how the demand for higher quality audits outside of the United States is affected by the type of institutional investors, foreign versus domestic. Consistent with the notion that FIIs (compared to DIIs) are more informationally disadvantaged, we find that FIIs demand high-quality audits in order to reduce the information asymmetry they face. This effect is stronger when the firms they invest in have severe information asymmetries, either at the country level or at the firm level.

Our findings highlight the monitoring role of FIIs in the international setting. By demanding highquality audits, FIIs monitor firms to reduce the information asymmetry, especially when FIIs originate from countries with stronger governance institutions. Consequently, FIIs spread high-quality disclosure practices from countries with stronger governance institutions to countries with weaker governance institutions. Our findings also underscore the role of Big 4 auditors as important information intermediaries and protectors of public trust, especially in countries or jurisdictions where other monitoring mechanisms (e.g., investor protection, disclosure requirements) are either weak or difficult to enforce. 


\section{References:}

Aggarwal, R., I. Erel, M. Ferreira, and P. Matos. 2011. Does governance travel around the world? Evidence from institutional investors. Journal of Financial Economics 100 (1):154-181.

- L. Klapper, and P. D. Wysocki. 2005. Portfolio preferences of foreign institutional investors. Journal of Banking \& Finance 29 (12):2919-2946.

Aier, J. K., L. Chen, and M. Pevzner. 2014. Debtholders' demand for conservatism: Evidence from changes in directors' fiduciary duties. Journal of Accounting Research 52 (5):993-1027.

Ajinkya, B., S. Bhojraj, and P. Sengupta. 2005. The association between outside directors, institutional investors and the properties of management earnings forecasts. Journal of Accounting Research 43 (3):343-376.

Armstrong, C. S., K. Balakrishnan, and D. Cohen. 2012. Corporate governance and the information environment: Evidence from state antitakeover laws. Journal of Accounting and Economics 53 (1):185-204.

Ayers, B. C., S. Ramalingegowda, and P. E. Yeung. 2011. Hometown advantage: The effects of monitoring institution location on financial reporting discretion. Journal of Accounting and Economics 52 (1):41-61.

Baik, B., J. Kang, J. Kim, J. Lee. 2013. The liability of foreignness in international equity investments: Evidence from the U.S. stock market. Journal of International Business Studies 44, 391-411.

Ball, R., S. Jayaraman, and L. Shivakumar. 2012. Audited financial reporting and voluntary disclosure as complements: A test of the confirmation hypothesis. Journal of Accounting and Economics 53 (1):136-166.

Becker, C. L., M. L. DeFond, J. Jiambalvo, and K. R. Subramanyam. 1998. The effect of audit quality on earnings management. Contemporary Accounting Research 15 (1):1-24.

Bena, J., M. A. Ferreira, P. P. Matos, and P. Pires. 2015. Are foreign investors locusts? The long-term effects of foreign institutional ownership. Working paper, University of Virginia-Darden School of Business.

Boone, A. L., and J. T. White. 2014. The effect of institutional ownership on firm transparency and information production. Journal of Financial Economics 117 (3), 508-533.

Bushee, B. J., and C. F. Noe. 2000. Corporate disclosure practices, institutional investors, and stock return volatility. Journal of Accounting Research 38: 171-202.

Bushman, R., and A. Smith. 2001. Financial accounting information and corporate governance. Journal of Accounting and Economics 32, 237-334.

Bushman, R. M., \& Piotroski, J. D. (2006). Financial reporting incentives for conservative accounting: The influence of legal and political institutions. Journal of Accounting and Economics, 42(1), 107-148.

Byard, D., Y. Li, and Y. Yu. 2011. The effect of mandatory IFRS adoption on financial analysts' information environment. Journal of Accounting Research 49 (1):69-96.

Carson, E. 2009. Industry specialization by global audit firm networks. The Accounting Review 84 (2):355-382.

Chang, X., S. Dasgupta, and G. Hilary. 2009. The effect of auditor quality on financing decisions. The Accounting Review 84 (4):1085-1117.

Choe, H., B. Kho, and R. M. Stulz. 2005. Do domestic investors have an edge? The trading experience of foreign investors in Korea. Review of Financial Studies 18 (3):795-829.

Choi, J. H., and T. J. Wong. 2007. Auditors' governance functions and legal environments: An international investigation. Contemporary Accounting Research 24 (1):13-46.

Choi, J. H., J.-B. Kim, X. Liu, and D. Simunic. 2008. Audit pricing, legal liability regimes, and Big 4 premiums: Theory and cross-country evidence. Contemporary Accounting Research 25 (1):55-99.

Chou, J., N. Zaiats, and B. Zhang. 2014. Does auditor choice matter to foreign investors? Evidence from foreign mutual funds worldwide. Journal of Banking \& Finance 46:1-20. 
Covrig, V. M., M. L. DeFond, and M. Hung. 2007. Home bias, foreign mutual fund holdings, and the voluntary adoption of international accounting standards. Journal of Accounting Research 45 (1):41-70.

Cui, C. (2016). MSCI Delays Adding China's Local Currency Shares to Emerging-Market Index. Wall Street Journal, June 14, 2016. Available at: http://www.wsj.com/articles/msci-delays-addingchinas-local-currency-shares-to-emerging-market-index-1465939738 . Accessed on July 3, 2016

Dahlquist, M., and G. Robertsson. 2001. Direct foreign ownership, institutional investors, and firm characteristics. Journal of Financial Economics 59 (3):413-440.

DeAngelo, L. E. (1981). Auditor size and audit quality. Journal of accounting and economics, 3(3), 183199.

DeFond, M., and J. Zhang. 2014. A review of archival auditing research. Journal of Accounting and Economics 58 (2):275-326.

, X. Hu, M. Hung, and S. Li. 2011. The impact of mandatory IFRS adoption on foreign mutual fund ownership: The role of comparability. Journal of Accounting and Economics 51 (3):240258.

Djankov, S., R. La Porta, F. Lopez-de-Silanes, and A. Shleifer. 2008. The law and economics of selfdealing. Journal of Financial Economics 88 (3):430-465.

El Ghoul, S., O. Guedhami, J. A. Pittman, and S. Rizeanu. 2015. Cross - country evidence on the importance of auditor choice to corporate debt maturity. Contemporary Accounting Research, Forthcoming

Eshleman, J. D., and P. Guo. 2014. Do Big 4 auditors provide higher audit quality after controlling for the endogenous choice of auditor? Auditing: A Journal of Practice \& Theory 33 (4):197-219.

Fan, J. P., and T. J. Wong. 2005. Do external auditors perform a corporate governance role in emerging markets? Evidence from East Asia. Journal of Accounting Research 43 (1):35-72.

Fang, V. W., M. Maffett, and B. Zhang. 2015. Foreign institutional ownership and the global convergence of financial reporting practices. Journal of Accounting Research 53 (3):593-631.

Ferreira, M. A., and P. Matos. 2008. The colors of investors' money: The role of institutional investors around the world. Journal of Financial Economics 88 (3):499-533. , M. Massa, and P. Matos. 2010. Shareholders at the gate? Institutional investors and crossborder mergers and acquisitions. Review of Financial Studies 23(2), 601-644.

Francis, J. R., Michas, P. N., \& Seavey, S. E. (2013). Does audit market concentration harm the quality of audited earnings? Evidence from audit markets in 42 countries. Contemporary Accounting Research, 30(1), 325-355. , C. Richard, and A. Vanstraelen. 2009. Assessing France's joint audit requirement: Are two heads better than one? Auditing: A Journal of Practice \& Theory 28 (2):35-63.

—, E. L. Maydew, and H. C. Sparks. 1999. The role of Big 6 auditors in the credible reporting of accruals. Auditing: A Journal of Practice \& Theory 18 (2):17-34.

—, and E. R. Wilson. 1988. Auditor changes: A joint test of theories relating to agency costs and auditor differentiation. Accounting Review 63(4), 663-682.

Gillan, S., and L. T. Starks. 2003. Corporate governance, corporate ownership, and the role of institutional investors: A global perspective. Journal of Applied Finance 13 (2), 4-22.

Guedhami, O., J. A. Pittman, and W. Saffar. 2009. Auditor choice in privatized firms: Empirical evidence on the role of state and foreign owners. Journal of Accounting and Economics 48 (2):151-171.

- - 2014. Auditor choice in politically connected firms. Journal of Accounting Research 52 (1):107-162.

Gul, F. A., G. S. Zhou, and X. K. Zhu. 2013. Investor protection, firm informational problems, Big N auditors, and cost of debt around the world. Auditing: A Journal of Practice \& Theory 32 (3):130.

Hail, L., and C. Leuz. 2006. International differences in the cost of equity capital: Do legal institutions and securities regulation matter? Journal of Accounting Research 44 (3):485-531. 
Han, S., T. Kang, and L. Rees. 2013. The association between institutional ownership and audit properties. Asia-Pacific Journal of Accounting \& Economics 20 (2):199-222.

Horton, J., G. Serafeim, and I. Serafeim. 2013. Does mandatory IFRS adoption improve the information environment? Contemporary Accounting Research 30 (1):388-423.

India Brand Equity Foundation. (2016, January). Foreign institutional investors. http://www.ibef.org/economy/foreign-institutional-investors.aspx\#sthash.zmQiB7U9.dpuf (accessed 27.01.16).

Jensen, M. C., and W. H. Meckling. 1976. Theory of the firm: Managerial behavior, agency costs and ownership structure. Journal of Financial Economics 3 (4):305-360.

Kang, J., and R. M. Stulz. 1997. Is bank-centered corporate governance worth it? A cross-sectional analysis of the performance of Japanese firms during the asset price deflation. National Bureau of Economic Research.

Khalil, S., M. L. Magnan, and J. R. Cohen. 2008. Dual-class shares and audit pricing: Evidence from the Canadian markets. Auditing: A Journal of Practice \& Theory 27 (2):199-216.

Kim, J., X. Liu, and L. Zheng. 2012. The impact of mandatory IFRS adoption on audit fees: Theory and evidence. The Accounting Review 87 (6):2061-2094.

La Porta, R., F. Lopez-de-Silanes, and A. Shleifer. 2006. What works in securities laws? Journal of Finance 61:1-32.

,,--- and R. Vishny. 1999. The quality of government. Journal of Law, Economics, and Organization 15 (1):222-279.

Lennox, C. 2005. Management ownership and audit firm size. Contemporary Accounting Research 22 (1):205-227.

Leuz, C., D. Nanda, and P. Wysocki. 2003. Investor protection and earnings management: An international comparison. Journal of Financial Economics 69 (3):505-527.

, K. V. Lins, and F. E. Warnock. 2010. Do foreigners invest less in poorly governed firms?

Review of Financial Studies 23 (3):3245-3285.

Lobo, G. J., \& Zhao, Y. (2013). Relation between audit effort and financial report misstatements:

Evidence from quarterly and annual restatements. The Accounting Review, 88(4), 1385-1412.

Lohade, N. (2016). MSCI says saudi stock market needs easier access for foreigners. Wall Street Journal, June 14, 2016. Available at: http://www.wsj.com/articles/msci-says-saudi-stock-marketneeds-easier-access-for-foreigners-1465952442 . Accessed on July 3, 2016.

Maffett, M. 2012. Financial reporting opacity and informed trading by international institutional investors. Journal of Accounting and Economics 54 (2):201-220.

Mansi, S. A., W. F. Maxwell, and D. P. Miller. 2004. Does auditor quality and tenure matter to investors? Evidence from the bond market. Journal of Accounting Research 42 (4):755-793.smfiimag.

MSCI. 2015. MSCI global investable market indexes methodology. https://www.msci.com/eqb/methodology/meth_docs/MSCI_Nov2015_GIMIMethodology.pdf

Petersen, M. A. 2009. Estimating standard errors in finance panel data sets: Comparing approaches. Review of Financial Studies 22 (1):435-480.

Pittman, J. A., and S. Fortin. 2004. Auditor choice and the cost of debt capital for newly public firms. Journal of Accounting and Economics 37 (1):113-136.

Skinner, D. J., and S. Srinivasan. 2012. Audit quality and auditor reputation: Evidence from Japan. The Accounting Review 87 (5):1737-1765.

Teoh, S. H., and T. J. Wong. 1993. Perceived auditor quality and the earnings response coefficient. Accounting Review 68 (2):346-366.

Tsang, A., F. Xie, and X. Xin. 2015. Foreign institutional investors and voluntary disclosure around the world. Working paper.

Watts, R. L., and J. L. Zimmerman. 1980. On the irrelevance of replacement cost disclosures for security prices. Journal of Accounting and Economics 2 (2):95-106. 
Weber, J., M. Willenborg, and J. Zhang. 2008. Does auditor reputation matter? The case of KPMG Germany and ComROAD AG. Journal of Accounting Research 46 (4):941-972.

Yu, G., and A. S. Wahid. 2014. Accounting standards and international portfolio holdings. The Accounting Review 89 (5):1895-1930. 


\section{Appendix. Variable Definitions}

\begin{tabular}{|c|c|}
\hline Variable & Definition \\
\hline \multicolumn{2}{|l|}{ Firm-Level Variables } \\
\hline Big4 & $\begin{array}{l}\text { An indicator variable equal to } 1 \text { if a firm's auditor is a Big } 4 \text { auditor, and } 0 \\
\text { otherwise. }\end{array}$ \\
\hline$T I O$ & $\begin{array}{l}\text { Percentage of shares (end-of-year) held by all types of institutional } \\
\text { investors. }\end{array}$ \\
\hline$F I O$ & $\begin{array}{l}\text { Percentage of shares (end-of-year) held by all foreign institutional } \\
\text { investors. }\end{array}$ \\
\hline FIO_HighGov & $\begin{array}{l}\text { Percentage of shares (end-of-year) held by foreign institutional investors } \\
\text { originating from countries with stronger governance institutions based on } \\
\text { sample median. Governance institutions are measured from three } \\
\text { dimensions: (1) investor protection, (2) disclosure requirement, and (3) } \\
\text { security regulations. }\end{array}$ \\
\hline FIO_LowGov & $\begin{array}{l}\text { Percentage of shares (end-of-year) held by foreign institutional investors } \\
\text { originating from countries with weaker governance institutions based on } \\
\text { sample median. Governance institutions are measured from three } \\
\text { dimensions: (1) investor protection, (2) disclosure requirement, and (3) } \\
\text { security regulations. }\end{array}$ \\
\hline $\mathrm{DIO}$ & $\begin{array}{l}\text { Percentage of shares (end-of-year) held by all domestic institutional } \\
\text { investors. }\end{array}$ \\
\hline Size & The log of a firm's of total assets in translated into U.S. dollars. \\
\hline $\operatorname{InvRec}$ & The sum of inventories and receivables divided by total assets. \\
\hline Capex & Capital intensity measured by long-term assets divided by total assets. \\
\hline Segs & Total number of business segments reported by a firm. \\
\hline$R O A$ & Net income divided by total assets. \\
\hline Leverage & Ratio of total debt to total assets. \\
\hline Fsale & Foreign sales as percentage of total sales. \\
\hline Growth & $\begin{array}{l}\text { Asset growth, measured as total assets minus total assets of last year } \\
\text { divided by total assets last year. }\end{array}$ \\
\hline Finance & $\begin{array}{l}\text { An indicator variable equal to one if long-term debt increased by } 20 \\
\text { percent or more or the number of shares outstanding increased by } 10 \\
\text { percent or more, and zero otherwise. }\end{array}$ \\
\hline \multicolumn{2}{|l|}{ Country-Level Variables } \\
\hline Earning Management (EM) & $\begin{array}{l}\text { The earnings management and opacity score developed by Leuz et al. } \\
\text { (2003). }\end{array}$ \\
\hline Disclosure Requirement (DR) & The disclosure requirement index from La Porta et al. (2006). \\
\hline IFRS Adoption (IFRS) & $\begin{array}{l}\text { An indicator variable which equals one if a country-year is for a country } \\
\text { which has adopted IFRS and a year which is during the post-adoption } \\
\text { period. }\end{array}$ \\
\hline Investor Protection (IP) & The anti-director rights index from Djankov et al. (2008). \\
\hline Law Origin (Law) & $\begin{array}{l}\text { An indicator variable equal to one if the origin of the commercial law of a } \\
\text { country is common law, and zero otherwise. }\end{array}$ \\
\hline Security Regulations (SR) & $\begin{array}{l}\text { The composite average of the disclosure requirement index, the liability } \\
\text { standard index, and the public enforcement index from La Porta et al. } \\
\text { (2006). }\end{array}$ \\
\hline
\end{tabular}


Table 1. Sample Characteristics by Country

This table presents the country distribution of firm-year observations in our sample. FIO (DIO) is the mean of firmlevel foreign (domestic) institutional ownership. FIO_V (DIO_V) is country-level market value of foreign (domestic) institutional ownership as a percentage of market value of all listed firms. All variables are defined in the Appendix.

\begin{tabular}{|c|c|c|c|c|c|c|c|c|}
\hline & Country & \# of Obs & \# of Firms & Big4 (\%) & FIO (\%) & DIO (\%) & FIO_V $(\%)$ & DIO_V $(\%)$ \\
\hline 1 & Argentina & 296 & 50 & 80.4 & 1.5 & 1.9 & 0.9 & 3.6 \\
\hline 2 & Australia & 5,688 & 1,249 & 69.4 & 3.8 & 1.4 & 9.0 & 2.0 \\
\hline 3 & Austria & 614 & 96 & 72.3 & 9.1 & 1.4 & 15.4 & 0.9 \\
\hline 4 & Belgium & 914 & 140 & 64.6 & 6.7 & 3.3 & 13.1 & 2.5 \\
\hline 5 & Brazil & 1,318 & 296 & 82.1 & 7.0 & 1.7 & 8.9 & 1.0 \\
\hline 6 & Canada & 10,160 & 2,184 & 73.3 & 6.6 & 14.2 & 23.6 & 26.1 \\
\hline 7 & Chile & 616 & 111 & 97.9 & 1.3 & 0.5 & 1.5 & 0.4 \\
\hline 8 & Denmark & 913 & 134 & 86.7 & 5.3 & 11.4 & 17.2 & 8.5 \\
\hline 9 & Egypt & 290 & 69 & 52.4 & 3.1 & 0.0 & 5.3 & 0.0 \\
\hline 10 & Finland & 1,061 & 136 & 91.7 & 10.2 & 8.9 & 23.2 & 5.1 \\
\hline 11 & France & 4,736 & 799 & 60.3 & 5.6 & 4.4 & 15.7 & 7.4 \\
\hline 12 & Germany & 4,858 & 790 & 56.7 & 6.9 & 5.3 & 16.5 & 7.7 \\
\hline 13 & Greece & 1,435 & 244 & 34.7 & 2.9 & 1.6 & 10.2 & 1.5 \\
\hline 14 & Hong Kong & 5,565 & 836 & 80.5 & 4.4 & 1.6 & 9.4 & 2.4 \\
\hline 15 & India & 4,697 & 1,054 & 19.1 & 4.0 & 3.6 & 7.9 & 2.5 \\
\hline 16 & Indonesia & 1,119 & 194 & 43.5 & 4.4 & 0.0 & 11.3 & 0.0 \\
\hline 17 & Ireland & 388 & 73 & 85.6 & 12.5 & 2.1 & 21.7 & 1.9 \\
\hline 18 & Israel & 1,471 & 406 & 56.8 & 2.2 & 8.2 & 6.2 & 9.0 \\
\hline 19 & Italy & 1,755 & 276 & 90.9 & 5.6 & 1.6 & 12.7 & 1.3 \\
\hline 20 & Japan & 24,586 & 3,406 & 57.7 & 3.0 & 1.1 & 8.2 & 1.2 \\
\hline 21 & Jordan & 63 & 17 & 52.4 & 0.5 & 0.0 & 0.3 & 0.0 \\
\hline 22 & Korea (South) & 5,352 & 989 & 65.6 & 5.0 & 0.2 & 13.7 & 0.1 \\
\hline 23 & Malaysia & 3,828 & 712 & 71.1 & 2.2 & 0.7 & 5.9 & 0.6 \\
\hline 24 & Mexico & 631 & 98 & 84.6 & 6.2 & 0.6 & 7.0 & 0.6 \\
\hline 25 & Netherlands & 1,158 & 180 & 90.7 & 14.1 & 7.3 & 25.5 & 3.1 \\
\hline 26 & New Zealand & 653 & 110 & 93.3 & 3.3 & 1.2 & 8.1 & 1.4 \\
\hline 27 & Norway & 1,162 & 228 & 94.1 & 7.3 & 9.9 & 14.4 & 8.7 \\
\hline 28 & Pakistan & 545 & 164 & 78.0 & 0.9 & 1.6 & 1.7 & 1.2 \\
\hline 29 & Peru & 155 & 31 & 88.4 & 2.1 & 0.1 & 2.5 & 0.0 \\
\hline 30 & Philippines & 695 & 108 & 89.1 & 4.3 & 0.1 & 8.8 & 0.1 \\
\hline 31 & Portugal & 395 & 56 & 63.3 & 4.3 & 3.4 & 12.0 & 1.5 \\
\hline 32 & Singapore & 2,679 & 468 & 82.6 & 3.8 & 1.4 & 9.5 & 5.7 \\
\hline 33 & South Africa & 1,632 & 308 & 75.2 & 3.6 & 6.2 & 10.2 & 4.2 \\
\hline 34 & Spain & 1,138 & 158 & 89.6 & 6.1 & 4.2 & 13.7 & 2.7 \\
\hline 35 & Sri Lanka & 104 & 27 & 95.2 & 5.0 & 0.0 & 6.1 & 0.0 \\
\hline 36 & Sweden & 2,381 & 398 & 90.0 & 6.7 & 14.3 & 14.6 & 20.3 \\
\hline 37 & Switzerland & 1,675 & 226 & 93.9 & 9.6 & 6.9 & 19.0 & 4.2 \\
\hline 38 & Taiwan & 5,438 & 1,029 & 86.0 & 3.5 & 0.8 & 10.7 & 0.7 \\
\hline 39 & Thailand & 1,772 & 305 & 68.4 & 4.0 & 1.0 & 6.4 & 1.2 \\
\hline 40 & Turkey & 1,271 & 208 & 64.9 & 4.2 & 0.1 & 8.4 & 0.1 \\
\hline 41 & United Kingdom & 11,309 & 2,033 & 65.7 & 4.1 & 15.2 & 12.8 & 10.5 \\
\hline
\end{tabular}


Table 2. Summary Statistics

This table presents the summary statistics of main variables in our sample. All variables are defined in the Appendix.

\begin{tabular}{lcccccccc}
\hline & $\mathrm{N}$ & $\mathrm{Mean}$ & $\mathrm{Std}$. & $\mathrm{p} 10$ & $\mathrm{p} 25$ & $\mathrm{p} 50$ & $\mathrm{p} 75$ & $\mathrm{p} 90$ \\
\hline Big4 & 116,516 & 0.674 & 0.469 & 0.000 & 0.000 & 1.000 & 1.000 & 1.000 \\
TIO & 116,516 & 0.099 & 0.132 & 0.002 & 0.009 & 0.047 & 0.137 & 0.276 \\
FIO & 116,516 & 0.048 & 0.074 & 0.000 & 0.002 & 0.014 & 0.061 & 0.143 \\
DIO & 116,516 & 0.051 & 0.092 & 0.000 & 0.000 & 0.010 & 0.057 & 0.160 \\
Size & 116,516 & 19.410 & 1.846 & 17.101 & 18.221 & 19.336 & 20.549 & 21.841 \\
Total Assets $(\mathrm{mil})$ & 116,516 & 1,540 & 4,522 & 26 & 81 & 249 & 840 & 3,057 \\
InvRec & 116,516 & 0.302 & 0.201 & 0.042 & 0.134 & 0.290 & 0.440 & 0.580 \\
Capex & 116,516 & 0.323 & 0.243 & 0.034 & 0.119 & 0.284 & 0.477 & 0.686 \\
Segs & 116,516 & 1.294 & 1.748 & 0.000 & 0.000 & 1.000 & 2.000 & 4.000 \\
ROA & 116,516 & 0.000 & 0.183 & -0.120 & -0.003 & 0.031 & 0.070 & 0.122 \\
Leverage & 116,516 & 0.124 & 0.145 & 0.000 & 0.001 & 0.073 & 0.199 & 0.332 \\
Fsale & 116,516 & 19.343 & 30.502 & 0.000 & 0.000 & 0.000 & 32.100 & 74.777 \\
Growth & 116,516 & 0.226 & 0.706 & -0.158 & -0.035 & 0.089 & 0.244 & 0.570 \\
Finance & 116,516 & 0.382 & 0.486 & 0.000 & 0.000 & 0.000 & 1.000 & 1.000 \\
\hline
\end{tabular}




\section{Table 3. The Effect of Foreign Institutional Ownership on Auditor Choice}

This table presents the estimation results of model (1). The dependent variable is Big 4 auditor choice. Foreign institutional ownership $(F I O)$ is the percentage of shares (end-of-year) held by all foreign institutional investors. In the parentheses below coefficient estimates, we report the robust $t$-statistics based on standard errors adjusted for heteroskedasticity and firm-level clustering. All continuous variables are winsorized at the 1st and 99th percentile. *, $* *$, and $* * *$ denote significance at the $0.1,0.05$, and 0.01 level, respectively. All variables are defined in the Appendix.

\begin{tabular}{|c|c|c|c|}
\hline & (1) & (2) & (3) \\
\hline TIO & $\begin{array}{l}2.890 * * * \\
(22.49)\end{array}$ & & \\
\hline$F I O$ & & $\begin{array}{l}4.570 * * * \\
(22.74)\end{array}$ & $\begin{array}{c}1.278^{* * *} \\
(6.17)\end{array}$ \\
\hline $\mathrm{DIO}$ & & $\begin{array}{c}1.513 * * * \\
(8.38)\end{array}$ & $\begin{array}{l}0.670 * * * \\
(3.83)\end{array}$ \\
\hline Size & & & $\begin{array}{l}0.292 * * * \\
(29.48)\end{array}$ \\
\hline $\operatorname{InvRec}$ & & & $\begin{array}{c}0.173^{* *} \\
(2.19)\end{array}$ \\
\hline Capex & & & $\begin{array}{l}0.219 * * * \\
(3.27)\end{array}$ \\
\hline Segs & & & $\begin{array}{l}0.023 \\
(1.16)\end{array}$ \\
\hline$R O A$ & & & $\begin{array}{l}0.372 * * * \\
(6.30)\end{array}$ \\
\hline Leverage & & & $\begin{array}{c}-0.310 * * * \\
(-3.28)\end{array}$ \\
\hline Fsale & & & $\begin{array}{c}0.001 * * \\
(2.05)\end{array}$ \\
\hline Growth & & & $\begin{array}{c}-0.083 * * * \\
(-7.68)\end{array}$ \\
\hline Finance & & & $\begin{array}{l}-0.010 \\
(-0.63)\end{array}$ \\
\hline Constant & $\begin{array}{c}1.278 * * * \\
(3.90)\end{array}$ & $\begin{array}{c}1.253 * * * \\
(3.79)\end{array}$ & $\begin{array}{c}-4.674 * * * \\
(-11.84)\end{array}$ \\
\hline $\begin{array}{l}\text { FIO-DIO } \\
\text { Chi2(1) }\end{array}$ & & $\begin{array}{l}3.057 * * * \\
(112.90)\end{array}$ & $\begin{array}{c}0.608^{* *} \\
(4.70)\end{array}$ \\
\hline Year, Industry, Country Effects & Included & Included & Included \\
\hline $\begin{array}{l}\text { Observations } \\
\text { Pseudo R2 }\end{array}$ & $\begin{array}{c}116,516 \\
0.17\end{array}$ & $\begin{array}{c}116,516 \\
0.17\end{array}$ & $\begin{array}{c}116,516 \\
0.20\end{array}$ \\
\hline
\end{tabular}


Table 4. The Effect of Country-Level Opacity on FIO-Auditor Relation

This table presents the estimation results of model (1) in subsamples. Country-level opacity is measured by Earnings Management $(E M)$ index in Panel A, Disclosure Requirement $(D R)$ in Panel B, and IFRS adoption (IFRS) in Panel C. In the parentheses below coefficient estimates, we report the robust $t$-statistics based on standard errors adjusted for heteroskedasticity and firm-level clustering. All continuous variables are winsorized at the 1st and 99th percentile. *, $* *$, and $* * *$ denote significance at the $0.1,0.05$, and 0.01 level, respectively. All variables are defined in the Appendix.

\begin{tabular}{|c|c|c|c|}
\hline \multicolumn{4}{|c|}{ Panel A: Earnings Management $(E M)$} \\
\hline & $(1)$ & (2) & $(1)-(2)$ \\
\hline & High EM & Low EM & \\
\hline FIO & $\begin{array}{c}1.227 * * * \\
(3.78)\end{array}$ & $\begin{array}{l}0.346 \\
(1.05)\end{array}$ & $\begin{array}{c}0.881 * * \\
(461)\end{array}$ \\
\hline $\mathrm{DIO}$ & $\begin{array}{l}-0.244 \\
(-0.57)\end{array}$ & $\begin{array}{c}0.856 * * * \\
(3.74)\end{array}$ & $\begin{array}{c}-1.100 * * \\
(5.66)\end{array}$ \\
\hline $\begin{array}{l}\text { FIO-DIO } \\
\text { Chi2(1) }\end{array}$ & $\begin{array}{c}1.471^{* *} \\
(6.44)\end{array}$ & $\begin{array}{l}-0.510 \\
(1.60)\end{array}$ & \\
\hline $\begin{array}{l}\text { Controls } \\
\text { Year, Industry, Country Effects } \\
\text { Observations } \\
\text { Pseudo R2 }\end{array}$ & $\begin{array}{c}\text { Included } \\
\text { Included } \\
61,663 \\
0.26 \\
\end{array}$ & $\begin{array}{c}\text { Included } \\
\text { Included } \\
46,611 \\
0.20 \\
\end{array}$ & \\
\hline \multicolumn{4}{|c|}{ Panel B: Disclosure Requirement $(D R)$} \\
\hline & (1) & (2) & $(1)-(2)$ \\
\hline & Low DR & High DR & \\
\hline FIO & $\begin{array}{c}1.308 * * * \\
(5.36)\end{array}$ & $\begin{array}{l}0.470 \\
(1.08)\end{array}$ & $\begin{array}{c}0.838^{*} \\
(2.82)\end{array}$ \\
\hline DIO & $\begin{array}{c}-1.230 * * * * \\
(-4.70)\end{array}$ & $\begin{array}{c}1.494 * * * \\
(5.73)\end{array}$ & $\begin{array}{c}-2.724 * * * \\
(54.39)\end{array}$ \\
\hline $\begin{array}{l}\text { FIO-DIO } \\
\text { Chi2(1) }\end{array}$ & $\begin{array}{c}2.538 * * * \\
(44.89)\end{array}$ & $\begin{array}{c}-1.024^{*} \\
(4.09)\end{array}$ & \\
\hline $\begin{array}{l}\text { Controls } \\
\text { Year, Industry, Country Effects } \\
\text { Observations } \\
\text { Pseudo } R 2\end{array}$ & $\begin{array}{c}\text { Included } \\
\text { Included } \\
74,179 \\
0.19\end{array}$ & $\begin{array}{c}\text { Included } \\
\text { Included } \\
42,337 \\
0.31\end{array}$ & \\
\hline \multicolumn{4}{|l|}{ Panel C: IFRS Adoption (IFRS) } \\
\hline & $(1)$ & $(2)$ & $(1)-(2)$ \\
\hline & $I F R S=0$ & $I F R S=1$ & \\
\hline FIO & $\begin{array}{c}2.282 * * * \\
(7.48)\end{array}$ & $\begin{array}{c}0.585^{* *} \\
(2.01)\end{array}$ & $\begin{array}{c}1.697 * * * \\
(10.76)\end{array}$ \\
\hline $\mathrm{DIO}$ & $\begin{array}{c}1.132 * * * \\
(4.30)\end{array}$ & $\begin{array}{c}1.023 * * * \\
(4.30)\end{array}$ & $\begin{array}{l}0.109 \\
(0.94)\end{array}$ \\
\hline $\begin{array}{l}\text { FIO-DIO } \\
\text { Chi2(1) }\end{array}$ & $\begin{array}{c}1.150 * * * \\
(7.63)\end{array}$ & $\begin{array}{l}-0.438 \\
(1.27)\end{array}$ & \\
\hline $\begin{array}{l}\text { Controls } \\
\text { Year, Industry, Country Effects } \\
\text { Observations } \\
\text { Pseudo R2 }\end{array}$ & $\begin{array}{c}\text { Included } \\
\text { Included } \\
81,349 \\
0.29\end{array}$ & $\begin{array}{c}\text { Included } \\
\text { Included } \\
35,167 \\
0.22 \\
\end{array}$ & \\
\hline
\end{tabular}


Table 5. The Effect of Firm-Level Opacity on FIO-Auditor Relation

This table presents the estimation results of model (1) in subsamples. Firm-level opacity is measured by firm size in Panel A, analysts following in Panel B, and earnings volatility in Panel C. In the parentheses below coefficient estimates, we report the robust $t$-statistics based on standard errors adjusted for heteroskedasticity and firm-level clustering. All continuous variables are winsorized at the 1 st and 99 th percentile. $*, * *$, and $* * *$ denote significance at the $0.1,0.05$, and 0.01 level, respectively. All variables are defined in the Appendix.

\begin{tabular}{|c|c|c|c|}
\hline \multicolumn{4}{|l|}{ Panel A: Firm Size } \\
\hline & $(1)$ & $(2)$ & (1)-(2) \\
\hline & Small Firm & Large Firm & \\
\hline FIO & $\begin{array}{c}1.948 * * * \\
(5.55)\end{array}$ & $\begin{array}{l}0.224 \\
(0.83)\end{array}$ & $\begin{array}{c}1.724 * * * \\
(15.83)\end{array}$ \\
\hline DIO & $\begin{array}{c}0.574 * * * \\
(2.66)\end{array}$ & $\begin{array}{c}0.656^{*} \\
(1.92)\end{array}$ & $\begin{array}{c}-0.082 \\
(0.04)\end{array}$ \\
\hline $\begin{array}{l}\text { FIO-DIO } \\
\text { Chi2(1) }\end{array}$ & $\begin{array}{c}1.374 * * * \\
(10.44)\end{array}$ & $\begin{array}{l}0.432 \\
(0.93)\end{array}$ & \\
\hline $\begin{array}{l}\text { Controls } \\
\text { Year, Industry, Country Effects } \\
\text { Observations } \\
\text { Pseudo R2 }\end{array}$ & $\begin{array}{c}\text { Included } \\
\text { Included } \\
58,255 \\
0.17\end{array}$ & $\begin{array}{c}\text { Included } \\
\text { Included } \\
58,261 \\
0.26\end{array}$ & \\
\hline \multicolumn{4}{|l|}{ Panel B: Analysts Coverage } \\
\hline & $(1)$ & $(2)$ & (1)-(2) \\
\hline & Low Coverage & High Coverage & \\
\hline $\begin{array}{l}\text { FIO } \\
\text { DIO }\end{array}$ & $\begin{array}{c}1.785 * * * \\
(4.63) \\
0.398 \\
(1.64)\end{array}$ & $\begin{array}{c}0.582 * * \\
(2.32) \\
0.042 \\
(0.19)\end{array}$ & $\begin{array}{l}1.203^{*} \\
(3.34) \\
0.356 \\
(0.26)\end{array}$ \\
\hline $\begin{array}{l}\text { FIO-DIO } \\
\text { Chi2(1) }\end{array}$ & $\begin{array}{c}1.387 * * * \\
(9.11)\end{array}$ & $\begin{array}{l}0.540 \\
(2.43)\end{array}$ & \\
\hline $\begin{array}{l}\text { Controls } \\
\text { Year, Industry, Country Effects } \\
\text { Observations } \\
\text { Pseudo R2 }\end{array}$ & $\begin{array}{c}\text { Included } \\
\text { Included } \\
61,158 \\
0.16 \\
\end{array}$ & $\begin{array}{c}\text { Included } \\
\text { Included } \\
55,358 \\
0.23 \\
\end{array}$ & \\
\hline \multicolumn{4}{|l|}{ Panel A: Earnings Volatility } \\
\hline & $(1)$ & $(2)$ & (1)-(2) \\
\hline & High Volatility & Low Volatility & \\
\hline$F I O$ & $\begin{array}{c}1.330 * * * \\
(4.88)\end{array}$ & $\begin{array}{c}0.796 * * * \\
(2.74)\end{array}$ & $\begin{array}{c}0.534 * \\
(3.45)\end{array}$ \\
\hline DIO & $\begin{array}{c}0.583 * * * \\
(2.76)\end{array}$ & $\begin{array}{c}0.691 * * \\
(2.49)\end{array}$ & $\begin{array}{c}-0.108 \\
(0.16)\end{array}$ \\
\hline $\begin{array}{l}\text { FIO-DIO } \\
\text { Chi2(1) }\end{array}$ & $\begin{array}{c}0.747 * * \\
(4.38)\end{array}$ & $\begin{array}{l}0.105 \\
(0.06)\end{array}$ & \\
\hline $\begin{array}{l}\text { Controls } \\
\text { Year, Industry, Country Effects } \\
\text { Observations } \\
\text { Pseudo R2 }\end{array}$ & $\begin{array}{c}\text { Included } \\
\text { Included } \\
57,791 \\
0.19 \\
\end{array}$ & $\begin{array}{c}\text { Included } \\
\text { Included } \\
57,785 \\
0.23 \\
\end{array}$ & \\
\hline
\end{tabular}




\section{Table 6. The Heterogeneity among FIIs and FIO-Auditor Relation}

This table presents the estimation results of model (2). The dependent variable is Big4. Foreign institutional ownership $(F I O)$ is split into foreign institutional ownership originated from countries with stronger governance institutions than the firm's country (FIO_HighGov) and foreign institutional ownership originated from countries with weaker governance institutions than the firm's country (FIO_LowGov), where governance institutions (Gov) are measured by investor protection (IP) in column (1), Law Origin $(L W)$ in column (2), and security regulations (SR) in column (3). In the parentheses below coefficient estimates, we report the robust $t$-statistics based on standard errors adjusted for heteroskedasticity and firm-level clustering. All continuous variables are winsorized at the 1st and 99th percentile. *, $* *$, and $* * *$ denote significance at the $0.1,0.05$, and 0.01 level, respectively. All variables are defined in the Appendix.

\begin{tabular}{|c|c|c|c|}
\hline & $\begin{array}{c}(1) \\
\text { Gov=Investor } \\
\text { Protection }\end{array}$ & $\begin{array}{c}(2) \\
\text { Gov=Law Origin }\end{array}$ & $\begin{array}{c}(3) \\
\text { Gov=Security } \\
\text { Regulations }\end{array}$ \\
\hline FIO_HighGov & $\begin{array}{l}1.138^{* * * *} \\
(3.13)\end{array}$ & $\begin{array}{l}2.416^{* * * *} \\
(8.65)\end{array}$ & $\begin{array}{l}1.451 * * * \\
(5.72)\end{array}$ \\
\hline FIO_LowGov & $\begin{array}{l}0.513 \\
(0.85)\end{array}$ & $\begin{array}{c}-2.274 * * * \\
(-4.03)\end{array}$ & $\begin{array}{c}0.823 \\
(1.34)\end{array}$ \\
\hline DIO & $\begin{array}{c}0.723 * * * \\
(4.10)\end{array}$ & $\begin{array}{c}0.716^{* * * *} \\
(4.06)\end{array}$ & $\begin{array}{c}0.674 * * * \\
(3.86)\end{array}$ \\
\hline Size & $\begin{array}{c}0.306 * * * \\
(31.51)\end{array}$ & $\begin{array}{c}0.293 * * * \\
(29.42)\end{array}$ & $\begin{array}{c}0.292 * * * \\
(29.32)\end{array}$ \\
\hline $\operatorname{InvRec}$ & $\begin{array}{c}0.157 * * \\
(1.99)\end{array}$ & $\begin{array}{c}0.173^{* *} \\
(2.18)\end{array}$ & $\begin{array}{c}0.174 * * \\
(2.20)\end{array}$ \\
\hline Capex & $\begin{array}{c}0.205 * * * \\
(3.06)\end{array}$ & $\begin{array}{c}0.225 * * * \\
(3.34)\end{array}$ & $\begin{array}{c}0.220 * * * \\
(3.28)\end{array}$ \\
\hline Segs & $\begin{array}{c}0.025 \\
(1.27)\end{array}$ & $\begin{array}{c}0.025 \\
(1.24)\end{array}$ & $\begin{array}{c}0.023 \\
(1.13)\end{array}$ \\
\hline$R O A$ & $\begin{array}{c}0.375 * * * \\
(6.34)\end{array}$ & $\begin{array}{c}0.363 * * * \\
(6.14)\end{array}$ & $\begin{array}{c}0.369 * * * \\
(6.26)\end{array}$ \\
\hline Leverage & $\begin{array}{c}-0.331 * * * \\
(-3.52)\end{array}$ & $\begin{array}{c}-0.300 * * * \\
(-3.18)\end{array}$ & $\begin{array}{c}-0.308 * * * \\
(-3.27)\end{array}$ \\
\hline Fsale & $\begin{array}{c}0.001 * * \\
(2.29)\end{array}$ & $\begin{array}{c}0.001 * * \\
(2.05)\end{array}$ & $\begin{array}{c}0.001 * * \\
(2.06)\end{array}$ \\
\hline Growth & $\begin{array}{c}-0.084 * * * \\
(-7.74)\end{array}$ & $\begin{array}{c}-0.084 * * * \\
(-7.68)\end{array}$ & $\begin{array}{c}-0.083 * * * \\
(-7.63)\end{array}$ \\
\hline Finance & $\begin{array}{l}-0.011 \\
(-0.64)\end{array}$ & $\begin{array}{l}-0.010 \\
(-0.60)\end{array}$ & $\begin{array}{l}-0.010 \\
(-0.62)\end{array}$ \\
\hline Constant & $\begin{array}{c}-4.925 * * * \\
(-12.49)\end{array}$ & $\begin{array}{c}-4.715^{* * * *} \\
(-11.91)\end{array}$ & $\begin{array}{c}-4.669^{* * * *} \\
(-11.81)\end{array}$ \\
\hline Year, Industry, Country Effects & Included & Included & Included \\
\hline $\begin{array}{l}\text { Observations } \\
\text { Pseudo } R 2\end{array}$ & $\begin{array}{c}116,516 \\
0.20\end{array}$ & $\begin{array}{c}116,516 \\
0.20\end{array}$ & $\begin{array}{c}116,516 \\
0.20\end{array}$ \\
\hline
\end{tabular}




\section{Table 7. Effects around Stock Additions to MSCI Index}

This table presents the effects of addition to MSCI on foreign institutional ownership, domestic institutional ownership, and Big 4 auditor choice. The dependent variable is FIO in column 1, DIO in column 2, and Big4 in column 3 . In the parentheses below coefficient estimates, we report the robust $t$-statistics based on standard errors adjusted for heteroskedasticity and firm-level clustering. All continuous variables are winsorized at the 1st and 99th percentile. *, $* *$, and $* * *$ denote significance at the $0.1,0.05$, and 0.01 level, respectively. All variables are defined in the Appendix.

\begin{tabular}{lccc}
\hline & $(1)$ & $(2)$ & $(3)$ \\
& FIO & DIO & Big4 \\
\hline & & & \\
Treated $\times$ Post & $0.033^{* * *}$ & 0.002 & $0.044^{* * *}$ \\
& $(10.57)$ & $(0.78)$ & $(3.74)$ \\
Firm Fixed Effects & & & \\
Observations & Included & Included & Included \\
Pseudo R2 & 3,990 & 3,990 & 3,990 \\
\hline
\end{tabular}


Table 8. 2SLS Regressions of the FIO-Auditor Relation

This table presents the results of 2SLS regressions of model (1), where we estimate a fitted value of foreign institutional ownership (FIO_Predicted) in the first stage, and then estimate equation (1) in the second stage with the fitted value of $F I O$ as the key independent variable. Column 1 presents the first-stage results with $F I O$ as the dependent variable. Column 2 presents the second stage results with the dependent variable as Big4. The instrument variables is Proximity, which is defined as the weighted average distance between the capital of a firm's home country and the capitals of all the other countries around the world, multiplied by negative one. The weight is the institutional investment outflow from each country divided by the aggregate institutional investment outflows from all countries. In the parentheses below coefficient estimates, we report the robust $t$-statistics based on standard errors adjusted for heteroskedasticity and firm-level clustering. All continuous variables are winsorized at the 1st and 99th percentile. *, **, and *** denote significance at the $0.1,0.05$, and 0.01 level, respectively. All variables are defined in the Appendix.

\begin{tabular}{l|cc}
\hline & $(1)$ & $(2)$ \\
Dep. Var. & FIO & \\
\hline \multirow{2}{*}{ Proximity } & & \\
& $4.943^{* * *}$ & \\
FIO_Predicted & $(3.43)$ & $7.911^{* * *}$ \\
DIO & & $(5.76)$ \\
& & $-0.944^{* * *}$ \\
Size & $0.143^{* * *}$ & $(-4.80)$ \\
& $(9.38)$ & $-0.088^{* * *}$ \\
InvRec & $0.019^{* * *}$ & $(-3.36)$ \\
& $(43.05)$ & $0.262^{* * *}$ \\
Capex & $-0.034^{* * *}$ & $(5.31)$ \\
& $(-11.35)$ & $0.204^{* * *}$ \\
Segs & $-0.024^{* * *}$ & $(5.70)$ \\
& $(-9.13)$ & $0.009^{*}$ \\
ROA & 0.001 & $(1.96)$ \\
& $(1.32)$ & $0.118^{* * *}$ \\
Leverage & -0.002 & $(9.26)$ \\
& $(-0.77)$ & $0.206^{* * *}$ \\
Fsale & $-0.035^{* * *}$ & $(4.03)$ \\
Growth & $(-9.22)$ & $-0.002^{* * *}$ \\
& $0.000^{* * *}$ & $(-4.88)$ \\
Finance & $(13.12)$ & $-0.029^{* * *}$ \\
& $0.001^{*}$ & $(-11.87)$ \\
Constant & $(1.95)$ & $-0.021^{* * *}$ \\
& $0.002^{* * *}$ & $(-5.05)$ \\
Year, Industry, Country Effects & $(3.55)$ & $2.362^{* * *}$ \\
Observations & $-0.298^{* * *}$ & $(4.83)$ \\
Pseudo R2 & $(-14.31)$ & Included \\
& & 116,516 \\
& Included & 0.19 \\
\hline & 116,516 &
\end{tabular}




\section{Table 9. Robustness Tests}

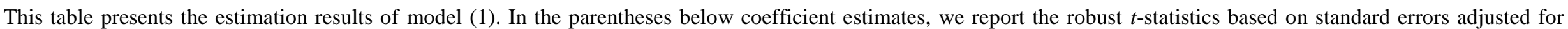

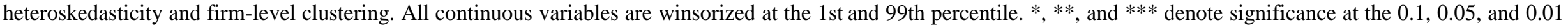
level, respectively. All variables are defined in the Appendix.

\begin{tabular}{|c|c|c|c|c|c|}
\hline & Audit Fee & $\begin{array}{c}(2) \\
\text { Industry } \\
\text { Specialization } \\
\text { Auditor }\end{array}$ & $\begin{array}{l}\text { (3) } \\
\text { Remove U.S. } \\
\text { Institutional } \\
\text { Investors }\end{array}$ & $\begin{array}{c}\text { (4) } \\
\text { Remove Top50 } \\
\text { Institutional Investor }\end{array}$ & $\begin{array}{c}\quad(5) \\
\text { Remove Major } \\
\text { Countries (UK, } \\
\text { CAN, JPN) }\end{array}$ \\
\hline $\mathrm{FIO}$ & $\begin{array}{c}0.904 * * * \\
(7.01)\end{array}$ & $\begin{array}{c}0.570 * * * \\
(2.87)\end{array}$ & $\begin{array}{c}0.849 * * * \\
(2.68)\end{array}$ & $\begin{array}{c}0.938 * * * \\
(3.89)\end{array}$ & $\begin{array}{c}0.929 * * * \\
(4.51)\end{array}$ \\
\hline $\mathrm{DIO}$ & $\begin{array}{c}0.205 * * \\
(2.09)\end{array}$ & $\begin{array}{c}-0.345^{*} \\
(-1.93)\end{array}$ & $\begin{array}{c}0.721 * * * \\
(4.10)\end{array}$ & $\begin{array}{c}-0.654 * * \\
(-2.54)\end{array}$ & $\begin{array}{c}0.699 * * * \\
(3.99)\end{array}$ \\
\hline Size & $\begin{array}{c}0.617 * * * \\
(84.01)\end{array}$ & $\begin{array}{c}0.367 * * * \\
(31.69)\end{array}$ & $\begin{array}{c}0.308 * * * \\
(32.01)\end{array}$ & $\begin{array}{c}0.311 * * * \\
(22.14)\end{array}$ & $\begin{array}{c}0.300 * * * \\
(30.48)\end{array}$ \\
\hline InvRec & $\begin{array}{c}0.429 * * * \\
(7.77)\end{array}$ & $\begin{array}{l}-0.066 \\
(-0.74)\end{array}$ & $\begin{array}{c}0.154^{*} \\
(1.94)\end{array}$ & $\begin{array}{l}-0.008 \\
(-0.08)\end{array}$ & $\begin{array}{c}0.166^{* *} \\
(2.10)\end{array}$ \\
\hline Capex & $\begin{array}{c}-0.538 * * * \\
(-11.43)\end{array}$ & $\begin{array}{c}-0.157 * * \\
(-2.12)\end{array}$ & $\begin{array}{c}0.200 * * * \\
(2.98)\end{array}$ & $\begin{array}{l}0.028 \\
(0.30)\end{array}$ & $\begin{array}{c}0.212^{* * * *} \\
(3.16)\end{array}$ \\
\hline Segs & $\begin{array}{c}0.124 * * * \\
(8.76)\end{array}$ & $\begin{array}{c}-0.049 * * \\
(-2.18)\end{array}$ & $\begin{array}{c}0.026 \\
(1.31)\end{array}$ & $\begin{array}{c}0.127 * * * \\
(4.64)\end{array}$ & $\begin{array}{l}0.025 \\
(1.24)\end{array}$ \\
\hline$R O A$ & $\begin{array}{c}-0.394 * * * \\
(-10.15)\end{array}$ & $\begin{array}{c}-0.140 * \\
(-1.90)\end{array}$ & $\begin{array}{c}0.374 * * * \\
(6.32)\end{array}$ & $\begin{array}{c}0.348 * * * \\
(4.21)\end{array}$ & $\begin{array}{c}0.373 * * * \\
(6.31)\end{array}$ \\
\hline Leverage & $\begin{array}{c}0.122 * \\
(1.80)\end{array}$ & $\begin{array}{c}-0.192 * \\
(-1.84)\end{array}$ & $\begin{array}{c}-0.334 * * * \\
(-3.55)\end{array}$ & $\begin{array}{c}-0.373 * * * \\
(-2.98)\end{array}$ & $\begin{array}{c}-0.323 * * * \\
(-3.42)\end{array}$ \\
\hline Fsale & $\begin{array}{c}0.004 * * * \\
(14.31)\end{array}$ & $\begin{array}{c}0.002 * * * \\
(3.10)\end{array}$ & $\begin{array}{c}0.001 * * \\
(2.34)\end{array}$ & $\begin{array}{l}0.000 \\
(0.71)\end{array}$ & $\begin{array}{c}0.001 * * \\
(2.18)\end{array}$ \\
\hline Growth & $\begin{array}{c}-0.022 * * * \\
(-2.83)\end{array}$ & $\begin{array}{c}-0.050 * * * \\
(-3.90)\end{array}$ & $\begin{array}{c}-0.084 * * * \\
(-7.73)\end{array}$ & $\begin{array}{c}-0.087 * * * \\
(-5.62)\end{array}$ & $\begin{array}{c}-0.084 * * * \\
(-7.70)\end{array}$ \\
\hline Finance & $\begin{array}{l}0.017 \\
(1.39)\end{array}$ & $\begin{array}{l}0.023 \\
(1.36)\end{array}$ & $\begin{array}{l}-0.010 \\
(-0.59)\end{array}$ & $\begin{array}{c}-0.064 * * * \\
(-2.92)\end{array}$ & $\begin{array}{l}-0.010 \\
(-0.61)\end{array}$ \\
\hline Constant & $\begin{array}{c}-10.256 * * * \\
(-19.84)\end{array}$ & $\begin{array}{c}-5.959 * * * \\
(-15.46)\end{array}$ & $\begin{array}{c}-4.959 * * * \\
(-12.61)\end{array}$ & $\begin{array}{c}-4.502 * * * \\
(-9.90)\end{array}$ & $\begin{array}{c}-4.816 * * * \\
(-12.21)\end{array}$ \\
\hline $\begin{array}{l}\text { Year, Industry, Country Effects } \\
\text { Observations } \\
\text { Pseudo R2 }\end{array}$ & $\begin{array}{c}\text { Included } \\
35,054 \\
0.92\end{array}$ & $\begin{array}{c}\text { Included } \\
116,516 \\
0.12\end{array}$ & $\begin{array}{c}\text { Included } \\
116,516 \\
0.20\end{array}$ & $\begin{array}{c}\text { Included } \\
70,461 \\
0.23\end{array}$ & $\begin{array}{c}\text { Included } \\
116,516 \\
0.20\end{array}$ \\
\hline
\end{tabular}

